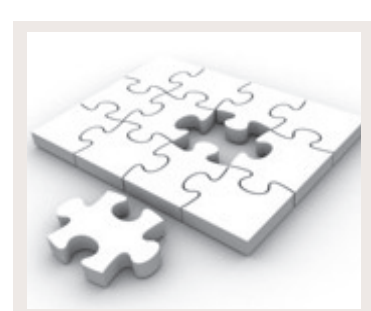

In 'n poging om die keuse van geskikte eweknieevalueerders vir die Suid-Afrikaanse Tydskrif vir Natuurwetenskap en Tegnologie te vergemaklik, versoek ons $\mathrm{u}$ om 'n oomblik af te staan om u elektroniese portfolio by http:/ / www.satnt. ac.za op datum te bring. Dit sal ons in staat stel om u belangstellingsveld en kundigheid beter te takseer sodat die voorgelegde manuskripte aan die geskikste eweknieevalueerders toegeken kan word. Indien u belangstel om ' $n$ evalueerder te word, word u versoek om die tydskrif se webwerf te besoek om as evalueerder te registreer. Om toegang tot $\mathrm{u}$ besonderhede op die webwerf te verkry, moet die volgende stappe gevolg word:

\section{Teken vir die} aanlynjoernaal in by http://www.satnt.ac.za.

2. Kies in u 'user home' [http://www.satnt.ac.za/ index.php/satnt/user] 'edit my profile' onder die opskrif 'my account' en tik alle relevante besonderhede, bio-verklaring en evalueringsbelangstellings in.

\section{Dit is goeie} evalueerderspraktyk om $\mathrm{u}$ persoonlike besonderhede gereeld op datum te bring om te verseker dat ons gedurende $u$ termyn as evalueerder vir die Suid-Afrikaanse Tydskrif vir Natuurwetenskap en Tegnologie met $\mathrm{u}$ in aanraking kan kom.

Moet asseblief nie huiwer om my te kontak vir verdere navrae nie.

Jana Venter submissions@satnt.ac.za

Tel: +27 (0)21 9752602

Fax: +27 (0)21975 4635

\title{
Suid-Afrikaanse Tydskrif vir
} Natuurwetenskap en Tegnologie

Die redaksionele span van die Suid-Afrikaanse Tydskrif vir Natuurwetenskap en Tegnologie erken hiermee die waardevolle, belangrike rol wat eweknie-evalueerders tydens die algehele publikasiesproses vervul - nie alleen in die vorming van individuele manuskripte nie, maar ook in die vestiging van die kredietwaardigheid en aansien van ons joernaal. Ons is daartoe verbind om alle oorspronklike, innoverende bydraes, wat vir publikasie voorgelê word, tydig te publiseer. Daarom is die identifisering en keuse van kundige evalueerders, met belangstelling in die onderwerpe wat deur elke manuskrip gedek word, 'n onontbeerlike element om 'n tydige, produktiewe eweknieevalueringsproses te verseker.

Ons wil graag van hierdie geleentheid gebruik maak om die volgende evalueerders vir hulle bydrae tot die vorming van hierdie uitgawe van die Suid-Afrikaanse Tydskrif vir Natuurwetenskap en Tegnologie te bedank:

Andries Stulting

Annemarie Hattingh

Annemarié Avenant-Oldewage

Ansie Harding

Arnold van der Westhuizen

Braam Pieterse

Calvyn Potgieter

Candice Janse Van Rensburg

Chris P.H. Myburgh

Christa Krüger

Corrie Kruger

Craig Grobbelaar

Dan Baird

Erna R. du Toit

Ewert P.J. Kleynhans

Gabriël F. du Toit

Gerrit H. Stols

Hanlie J.J. Botha

Hannalene du Plessis

Hannes van Wyk

Ina Louw

Jacobus N. Eloff

Jacques Pietersen

Jan Lochner

Johan U. Grobbelaar

Johanna G. Ferreira
Johannes van Rooyen

John J. Barnard

Josef J. de Beer

Lesley le Grange

Lize Joubert

Marc de Vries

Marie Poggenpoel

Mark Maboeta

Marthie S. van der Walt

Mia Abrie

Michelle Finestone

Neal T. Petersen

Piet King

Pieter Theron

Rian de Villiers

Ronel Ferreira

Sophie Reinecke

Surette van Staden

Susan Dippenaar

Theuns Erasmus

Vernon Louw

Wessel Pienaar

Willem J. Rauscher

William J. Fraser

Wilmien Luus-Powell

Wynand J. Boshoff

Ons waardeer $u$ tyd en bydrae tot die suksevolle evaluasie van die artikels. 